\title{
IV. Die Aufgabe der Medizin und ihre Wissenschaft: Wissenschaftlichkeit als Kompromiss zwischen Wirkungsspezifität und Praxissensitivität/ The Mission of Medicine and Its Science: Scientific Soundness Is a Compromise between the Specificity of an Effect and Its Sensitivity to Practice
}

\section{Kommentar des Herausgebers}

Medizinische Wissenschaft begreift wahrscheinlich nur in glücklichen Zeiten eines Erkenntnisdurchbruchs treffend, «worauf es ankommt»; dann kann medizinische Theorie so treffend sein, dass ihre Wirkungsspezifität und ihre Praxissensitivität beide gut sind. Die mittelalterliche Medizin mit einer lebendigen Theologie als Grundlagenwissenschaft hatte vermutlich am Anfang eine solche Zeit (bevor die Kirche aus dieser Grundlagenwissenschaft eine Ablassindustrie zur Prävention des Fegefeuers fabrizierte), und ebenso scheint es, dass die naturwissenschaftliche Medizin eine solche gute Zeit hatte, bevor sie immer mehr der Illusion neureicher Gesellschaften verfiel, medizin-technische Fortschritte könnten das Sterben verhindern. Die naturwissenschaftliche Medizin wurde mit einigem Erfolg an den wenigen, meist ernsthaft kranken Patienten in Krankenhäusern entwickelt, wo allein die aufwendige naturwissenschaftliche Technologie aufgebaut werden konnte. Erst seit relativ kurzer Zeit wird der Misserfolg dieser Medizin erkenntlich, als sie sich angeschickt hatte, ihre Krankenhauserfolge auf ambulante Praxen, die zunehmend durch spezialisierte Ärzte geführt wurden, und sogar auf gesunde Populationen auszudehnen, was nun technisch möglich war. Solange die Gesellschaften es sich nicht leisten konnten, spezialisierte Medizin über eine kleine Krankenhausbettenzahl hinaus zur Verfügung zu stellen, war die dort geübte naturwissenschaftliche Medizin mit ihren Wirkungsmöglichkeiten recht «spezifisch», gleichzeitig aber auch recht «sensitiv“, da die wissenschaftliche Medizin auf die Krankenhäuser beschränkt blieb, wo sie ihre externe Validität besass. Draussen in den Praxen wurde trotz Studiums der Anatomie und Physiologie recht pragmatisch gelindert und getröstet, für medizin-technologische Heilsversprechen etwa in Form präventiver Untersuchungen und des Checkup reichte die Zeit gar nicht. Dies ist heute ganz anders, und nur dieser gewaltige Wandel im Spektrum der Gesundheitsstörungen, die heute in den Händen naturwissenschaftlicher Medizin behandelt werden, lässt verstehen, weshalb die durch fest sozialisierte Denkgewohnheiten geleitete medizinische Profession derart unfähig ist, die fehlende Prädiktivität ihrer «naturwissenschaftlichen» Instrumente in der Situation niedriger Krankheits-

\section{Editorial Commentary}

It is probably only in the happy times of a scientific breakthrough that medical science suitably comprehends 'what the heart of the matter is'; in such a case medical theory can be so appropriate that both the specificity of its treatments and its sensitivity in practice are good. Mediaeval medicine, with percipient theology as its basic science, presumably had such a phase at the beginning (before the church turned this science into an indulgence industry for avoiding purgatory) and it similarly appears that natural science-based medicine experienced such 'happy times' before it began succumbing to the illusion of nouveau-riche societies that medical and technical progress might save people from dying. Natural science-based medicine was developed with some success on the few, mostly very sick patients in hospitals, the only place where the elaborate natural science-based technology could be set up. The increasing failure of this kind of medicine has come to light only recently, since medicine started to apply the successes it achieved in hospital to ambulatory patients, who were increasingly treated by specialised doctors, and even to healthy populations once this had become technically feasable. As long as society could not afford to provide specialised medicine to more people than the small number of hospital beds allowed, the natural science-based medicine practised back then was actually very 'specific' in its achievements and at the same time quite 'sensitive' as long as it was restricted to hospitals where its external validity was given. Outside in the medical practices and despite the doctors' training in anatomy and physiology, the patients were relieved and comforted in a very pragmatic and mostly empiric fashion. There was precious little time for promises of cures and salvation from medical technology like preventive tests or check-ups. Now, all this has changed, and it is only the gigantic transformation in the spectrum of health disorders treated today by the practitioners of natural science-based medicine that helps us understand why the medical profession guided by the old habits of thinking fails to recognise the poor predictive value of its 'natural science-based' instruments in low disease probability situations [1]. Indeed, many specific instruments available to modern medicine are quite useless in most of the situations in which 
wahrscheinlichkeiten zu erkennen [1]. Die vielen spezifischen Instrumente der modernen Medizin sind für die meisten Situationen, in denen Medizin praktiziert wird, nämlich kaum brauchbar. Der Informationsgewinn ist meist gering und/oder geht am Problem vorbei. So ist auch das Instrument der klinischen Studie einseitig auf eine pharmakologische Spezifität getrimmt worden, so dass wichtige praktisch-klinische Fragen durch die Ergebnisse heutiger Studien unbeantwortet bleiben, die sich oft an zwar «spezifischen», aber nebensächlichen Fragen orientieren [2].

Zur Frage, wie dieser Verlust an praktisch relevanter Information zu kurieren ist, äusserte sich zum Beispiel Alvan Feinstein am 1. Einsiedler Symposium [3, 4]: «As we go into the 21st century, we need to give scientific and humanistic analysis to asking patients and getting answers to four old questions that go back, not merely to Paracelsus, but even to Hippocrates. These questions reflect the oldest and most profound information in our clinical heritage. Those four questions to the patient are: (1) How are you? (2) What would you like done? Then later, after we have done our act of healing or whatever it might have been, we ask (3) How are you now? and (4) How well was it done? To the extent that we pay attention to that kind of information, we will be good healers. To the extent that we incorporate the information into the science used for evaluating our healing, we will also be healing scientists. (...) We need to get clinical evidence of relief and comfort, not just cure. Our statistical colleagues have diverted us into a hard data creed, which we have willingly accepted. We have therefore sought evidence of cure, while ignoring evidence of relief and comfort. We have thus forsaken the clinician's ancient obligation: to cure occasionally, to relieve often, and to comfort always.»

Der Beitrag von Leanne Roberts et al. weist darauf hin, dass selbst so «unmedizinische» und unspezifische Interventionen wie das Beten für Kranke im Rahmen kontrollierter Studien auf ihre Wirkung überprüft werden können (vgl. auch [5]) und dass für die Interpretation der Ergebnisse solcher Studien die gleichen methodischen Regeln gelten wie für konventionellere Behandlungen. Auf den Krankheitsverlauf im üblichen Sinn scheint das Fürbitten keinen Einfluss zu haben (so wenig wie auch die moderneren Absolutionstechniken des Pap-Abstrichs oder der Brustabtastung, welche ohne präventive Wirkung sind). Vielleicht ist aber der heute im Vordergrund stehende klinische Endpunkt eines längeren oder komplikationsfreieren Lebens gar nicht so relevant, das Beten will jedenfalls die Erlösung und nicht das lange Leben, auch wenn eine solche Wertsetzung für uns heute eine eher zynische Konnotation hat. Dieser kleine Exkurs wäre unnütz, wenn wir nun streiten, was «wahr» ist. Wichtiger ist die Wirkung (die externe Validität) von «Wahrheit»; Erlösung als Ziel menschlichen Lebens kann für die einen unerwünscht zynisch wirken, für die anderen aber ein hilfreich tröstliches Reframing bewirken. Die Ziele medizinischer Intervention haben keine ewige Gültigkeit und entsprechen einem Konsens. Der moderne Konsens ist indessen brüchig geworden, und die vielen Wahrheiten der heutigen Postmoderne können erst mit der Zeit in einen neuen Konsens münden. Die moderne Medizin hat biologische Phänomene oft mehr mit politisch-gesellschaft- medicine is now practised. The gain in information is usually minimal and/or misses the problem. Similarly, the instrument of the clinical trial is trimmed for one-sided questions of pharmacological specificity, with important practical clinical questions remaining unanswered by the results of today's studies; these are often orientated along 'specific", but often irrelevant questions [2].

How can this loss of practically relevant information be cured? Alvan Feinstein gave one answer at the 1st Scientific Symposium of Einsiedeln [3, 4]: 'As we go into the 21st century, we need to give scientific and humanistic analysis to asking patients and getting answers to four old questions that go back, not merely to Paracelsus, but even to Hippocrates. These questions reflect the oldest and most profound information in our clinical heritage. These four questions to the patient are: (1) How are you? (2) What would you like done? Then later after we have done our act of healing or what ever it might have been, we ask (3) How are you now? and (4) How well was it done? To the extent that we pay attention to that kind of information, we will be good healers. To the extent that we incorporate the information into the science used for evaluating our healing, we will also be healing scientists. (...) We need to get clinical evidence of relief and comfort, not just cure. Our statistical colleagues have diverted us into a hard data creed, which we have willingly accepted. We have therefore sought evidence of cure, while ignoring evidence of relief and comfort. We have thus forsaken the clinician's ancient obligation: to cure occasionally, to relieve often, and to comfort always.'

The report by Leanne Roberts et al. indicates that the efficacy of even such 'unmedical' and non-specific interventions like intercessory praying can be tested within controlled trials (cf. [5]) and that the same methodological rules apply to the interpretation of the results of such studies as to conventional therapies. Intercession does not appear to have any impact on the course of the disease in conventional terms (equally as little impact as more modern absolution techniques like the Pap smear or breast self-examination which have no preventive effect). Might it be that perhaps the currently so predominant clinical endpoint of a longer or more complication-free life is really not that relevant; at any rate, praying aims at redemption, not longer life, even if such moral values have a rather cynical connotation for many of us in this day and age. This brief digression would be useless if we were to start arguing about what is 'true'; rather it is the effect (the external validity) of 'truth' that is more important. Redemption as an aim of human life may sound adversely cynical to one person, but to another it may lead to a helpful and comforting reframing process. The aims of medical intervention have no eternal validity and they are just the result of a consensus. The modern consensus has meanwhile become fragile, and the many truths of today's post-modern age will merge together to form a new consensus only with time. Modern medicine tends to handle phenomena more with socio-political conformism than with the methods of sound science, which partly explains the above-mentioned inability of the medical profession to recognise the lacking strength of its presumed 'objective' instruments now that it is faced with a completely changed patient popu- 
licher Konformität denn mit dem Mittel durchdachter Wissenschaft behandelt, was die bereits erwähnte Unfähigkeit der medizinischen Profession miterklärt, die fehlende Aussagekraft ihrer vermeintlich «objektiven» Instrumente angesichts eines völlig gewandelten «Patientengutes» zu erkennen. David Hadorn zeigt in seinem Beitrag sehr schön auf, wie die Medizin die Meinungen von Patienten als «subjektiv», als «nur Placebo» etc. behandelt, wenn ihre «objektiven» Tatsachen mit diesen in Konflikt geraten. Die «Messung» subjektiver Besserung ist heute methodisch hochentwickelt, was Hadorn kurz und witzig erläutert (und was anderswo unter dem Begriff «Klinimetrie» umfassend aufgearbeitet ist [6]). Der orthopädische Chirurg Luzi Dubs nennt seinen Beitrag «Der Patient als Experte» und legt in unkomplizierter und überzeugender Sprache dar, wie viel entscheidender der individuelle Fähigkeitsgewinn gegenüber der Perfektion der Organreparatur ist, die auch ohne chirurgische Nachhilfe durch Selbstheilung sehr oft zufriedenstellend gelingt. Mit der Internationalen Klassifikation der Schädigungen, Fähigkeitsstörungen und Beeinträchtigungen (ICIDH) liegt bereits heute eine Nosologie vor, welche Wirtsfaktoren einschliesst und sensitiv für die Belange des Patienten (und nicht nur für seine Organe) ist. Dubs' MARA-Modell («mean agerelated ability») ist eine ausgezeichnete Arbeitsgrundlage zur pragmatischen Festlegung eines patientenorientierten Behandlungsziels (auch wenn dieses Modell in der Funktion als Erfolgsmass für die Beurteilung des Behandlungsnutzens für verschiedene Krankheiten und Störungen noch weiterentwickelt und validiert werden muss). Gisela C. Fischer zeigt mit ihrer umfassenden Darstellung allgemeinmedizinischer Patientenprobleme die grossen Forschungslücken auf, die neben und nach der Evolution und Evaluation einer Therapie unter Idealbedingungen im Bereich des Transfers und der Implementation in die komplexe Situation der Praxis bestehen, und führt die Diskussion auf den wichtigen Punkt, dass in der Praxis in der Regel die Wirkung therapeutischer Strategien und nicht die einzelner Wirkstoffe zur Diskussion steht. Fischer weist wie schon Dubs sehr treffend darauf hin, dass die überholte und irrtümliche Gleichsetzung von biologischer Wirkung mit Patientennutzen zum ungenügenden Preis-Leistungs-Verhältnis der modernen Medizin geführt hat, welches nicht nur aus ökonomischen Gründen, sondern auch wegen iatrogener Gefahren eine Korrektur erfordert. Wie ich in meinem eigenen Beitrag darlege, wissen wir aufgrund der verspäteten wissenschaftlichen Analysen heute, dass mit dem Cholesterinscreening mehr Menschen umgebracht als gerettet worden sind. Dies wird ersichtlich, wenn der Praxiskontext in Form der «number needed to treat» analysiert wird und die fehlende externe Validität beim Transfer biologischer Wirkungen in verschiedene Patientengruppen bzw. Risikopopulationen erkannt wird. Das teuer gewordene Sich-Kaprizieren der Medizin auf spezifische biologische Effekte und auf die Entwicklung und Massenproliferation spezialisierter Techniken, ohne sich über deren Nutzen und Relevanz in der komplexen, «störenden» Praxis ausreichend Gedanken zu machen, erfährt heute eine (noch sehr langsame) Ablösung durch eine pragmatische klinische Forschung, die auch (randomisierte) Vergleiche ganzer Therapiestrategien in Angriff nimmt. Damit werden mindestens punktuell auch lation. David Hadorn's report illustrates very nicely how medicine handles patients' opinions as 'subjective', as 'only placebo effects' etc. when these opinions come into conflict with the profession's 'objective' facts. Today, the methods of 'measuring' subjective improvement have become highly developed, which Hadorn briefly and humorously details (a subject that has been comprehensively dealt with elsewhere under the heading of 'clinimetrics' [6]). The orthopaedic surgeon Luzi Dubs used the subheading 'Patients as Experts' for his contribution, in which he explains in straightforward and convincing language how much more crucial the individual gain in performance ability is compared to the perfection of organ repair which very often is accomplished satisfactorily by self-healing without any surgical intervention. The International Classification of Impairments, Disorders and Handicaps (ICIDH) now provides us with a nosology which incorporates host factors and, at the same time, is sensitive to the concerns of the patients (and not only to his organs). Dubs's MARA model (mean age-related ability) provides an excellent working basis for pragmatically establishing patient-orientated treatment goals (even though this model must still be further developed and validated as an instrument in assessing therapeutic outcome for various diseases and disorders). In her comprehensive presentation of the problems patients have in general practice, Gisela $C$. Fischer exposed the large research gaps that arise in parallel to and after the evolution and evaluation of best-case therapies when it comes to transferring and implementing them into the complex practical setting. She focused the discussion on the important point that, in practice, the effect of therapeutic strategies and not that of individual agents or other treatment components is usually the centre of the discussion. Like Dubs before her, Fischer points out that it is outdated and erroneous to equate biological effect with benefit for the patient and that this has led to an inadequate cost-performance ratio in modern medicine. This imbalance must be corrected, not just for economic reasons, but because of the iatrogenic risks. As I illustrate in my own report, we now know from belated scientific analyses that more people have been killed by cholesterol screening than have been saved. This becomes evident if the practical context is analysed based on the 'number needed to treat' concept and once it has been recognised that external validity may be lacking when biological effects are transferred to different patient groups or risk populations. Medicine's present expensive focus on specific biological effects and the development and mass proliferation of specialised techniques, without taking enough time to think about their usefulness in and relevance to complex and 'confounding' practical applications is now being redirected (although very gradually) by pragmatic clinical research that also deals with (randomised) comparisons of entire therapeutic strategies. Thereby, at least some complex, individualised treatments in general medicine, complementary medicine as well as in psychotherapy will be made accessible to testing in randomised trials. In the end, this is the only way that the indication-related performance of various medicines can be established (and sometimes even then only serving as general guide). What matters here is that patient inclusion criteria in studies be defined in a equally pragmatic and innovative way that 
komplexe, individualisierte Behandlungen der Allgemeinmedizin, der Komplementärmedizin und der Psychotherapie der Überprüfung in randomisierten Studien zugänglich, denn die indikationsbezogene Leistungsfähigkeit verschiedener medizinischer Disziplinen lässt sich am Schluss nur so feststellen (wenn auch vielleicht nur als grobe Orientierung). Entscheidend dabei ist eine ebenso pragmatische wie innovative Definition des untersuchten Krankheitsbildes über die phänomenologisch beschränkte, unsensible ICD-Klassifikation hinaus. goes beyond the phenomenologically limited ICD classification with its low sensitivity for the complex practice doctors deal with in the end.

\section{Literatur/References}

1 Sox HC, Blatt MA, Higgins MC, Marton KI: Medical Decision Making. Boston, Butterworth-Heinemann, 1988.

2 Feinstein AR, Horwitz RI: Problems in the 'Evidence' of 'Evidence-based medicine'. Am J Med 1997;103;529-535.

3 Feinstein AR: The hard data creed in current clinical practice: Its spurious validity and the challenge to define meaningful clinical variables, in Schmidt JG, Steele RE (eds): Kritik der medizinischen Vernunft: Schritte zu einer zeitgemässen Praxis - Ein Lesebuch. Mainz, Verlag Kirchheim, 1994, pp 210-218. (Deutsch: Das irreführende Credo harter Daten in der heutigen klinischen
Praxis - das Problem sinnvoller klinischer Erfolgskriterien. Forsch Komplementärmed 1994;1:260-265).

4 Feinstein AR: Why do we need clinical epidemiology? A practice-oriented clinical science, in Schmidt JG, Steele RE (eds): Kritik der medizinischen Vernunft: Schritte zu einer zeitgemässen Praxis - Ein Lesebuch. Mainz,Verlag Kirchheim, 1994, pp 233-243.

5 Joyce CRB: Is God a placebo? Forsch Komplementärmed 1998;5(suppl 1):4751.

6 Feinstein AR: Clinimetrics. New Haven, Yale University Press, 1987. 